ALOHA AMERICA 

Adria L. Imada

\section{ALOHA AMERICA}

HULA CIRCUITS THROUGH THE U.S. EMPIRE

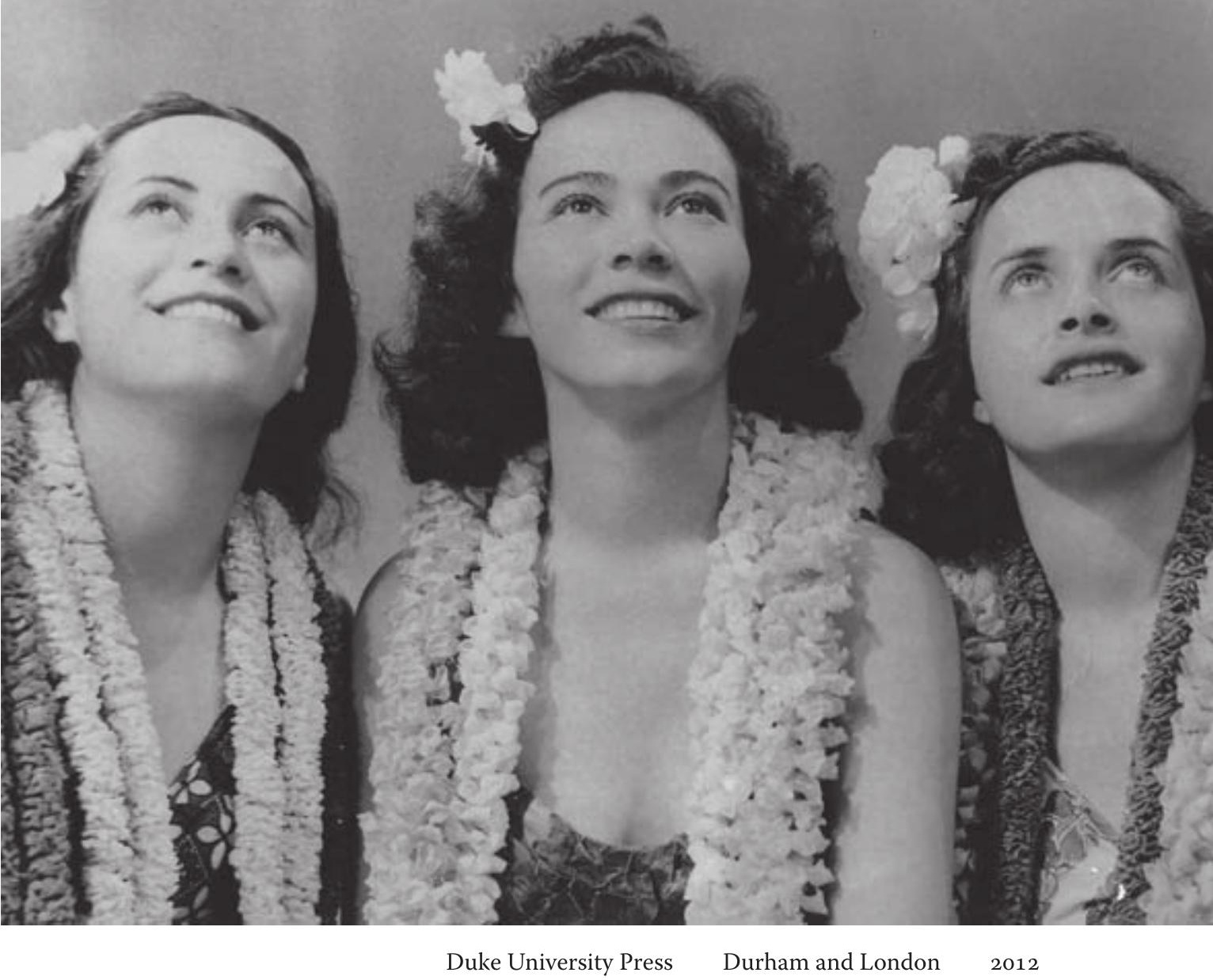


C 2012 Duke University Press

All rights reserved

Printed in the United States of America on acid-free paper $\infty$ Designed by Heather Hensley

Typeset in Warnock Pro by Copperline Book Services, Inc.

Library of Congress Cataloging-in-Publication Data appear on the last printed page of this book.

An earlier version of chapter 4 was published as "Hawaiians on Tour: Hula Circuits through the American Empire" in American Quarterly 56, no. 1 (March 2004). Portions of chapter 5 were previously published as "The Army Learns to Luau: Imperial Hospitality and Military Photography in Hawai' $\mathrm{i}$ ' in The Contemporary Pacific 20, no. 2 (2008). 
Many times I have watched the ships sail in and out of the port of Honolulu, and many times the question came to my mind. Who made this great world? Why are people different? Why are there different ways of talking? What does the world look like away from here, far away?

Victoria Nalani Kneubuhl, The Conversion of Ka'ahumanu 
